\title{
PERANCANGAN INSTRUMENTASI PENGUKUR WAKTU DAN KECEPATAN MENGUNAKAN DT-SENSE INFRARED PROXIMITY DETECTOR UNTUK PEMBELAJARAN GERAK LURUS BERATURAN
}

\author{
${ }^{1)}$ Choirun Nisa, ${ }^{1)}$ Nurfitria Widya P, 1) Aji Santosa, ${ }^{1)}$ Endah Rahmawati \\ ${ }^{1)}$ Prodi Pendidikan Fisika Jurusan Fisika FMIPA UNESA \\ ${ }^{*}$ Email: nisa.itu@gmail.com
}

\begin{abstract}
Abstrak
Fisika merupakan bagian dari sains yang memahami segala sesuatu tentang gejala-gejala alam yang terjadi. Banyak sekali fakta di sekolah-sekolah bahwa pelajaran fisika merupakan pelajaran yang sulit dipahami dan membosankan. Konsep dan rumus yang telah disampaikan oleh guru biasanya hanya digunakan dalam penyelesaian soal-soal saja dan siswa cenderung bosan dan sulit untuk memahami konsep tersebut. Sehingga diperlukan media untuk membantu proses belajar-mengajar misalnya media percobaan/eksperimen. Dalam percobaan membutuhkan perangkat antara lain instrumentasi dan bahan sesuai dengan percobaan yang akan dilakukan. Instrumentasi laboratorium sebagai penunjang percobaan yang akan membantu siswa memahami materi yang diajarkan, sering tidak dijumpai di sekolah-sekolah. Dalam penelitian ini dilaksanakan untuk merancang instrumentasi pengukur waktu dan kecepatan sebagai media pembelajaran materi gerak lurus beraturan. Penelitian ini diharapkan dapat menarik siswa dalam belajar materi fisika khususnya gerak lurus beraturan, sehingga dapat mewujudkan hasil belajar siswa yang maksimal. Dari hasil penelitian ini diperoleh DT Sense Infrared Proximity Detector dapat digunakan dalam perancangan instrumentasi pengukur waktu dan kecepatan. Dan hasil penelitian ini dapat digunakan sebagai media penunjang yang akan membantu siswa ataupun mahasiswa dalam memahami materi fisika khususnya materi gerak lurus beraturan.
\end{abstract}

Kata Kunci : DT-Sence Infrared Proximity Detector, waktu, kecepatan, gerak lurus beraturan. 


\section{PENDAHULUAN}

Dalam konteks tersebut diatas, diperlukan media pembelajaran untuk membantu proses belajar-mengajar siswa. Harapan dari adanya media pembelajaran adalah siswa dapat tertarik dalam belajar materi fisika, sehingga dapat mewujudkan hasil belajar siswa yang maksimal. Media pembelajaran yang dapat membantu proses belajar siswa misalnya, media percobaan/eksperimen ataupun media simulasi.

Media percobaan/eksperimen sebagai sarana membantu proses belajar mengajar membutuhkan perangkat antara lain alat dan bahan sesuai dengan percobaan yang akan dilakukan. Misalnya, percobaan untuk praktikum listrik dinamis dibutuhkan perlengkapan pendukung seperti avometer/multimeter untuk mengukur besarnya arus, tegangan, hambatan pada rangkaian, resistor dan juga baterai. Untuk materi lain yang erat berhubungan dengan gerak lurus beraturan diperlukan alat yang lebih modern, misalnya keluaran Pasco Scientific misalnya, Pasco Dynamics Carts ME-6950, Pasco Strack Dynamics System ME-6961, dan Photogate timer Model ME9204.

Alat atau instrumen laboratorium sebagai penunjang percobaan yang akan membantu siswa memahami materi yang diajarkan, sering tidak dijumpai di sekolahsekolah. Hal ini karena dana yang diperlukan untuk membeli dan merawat instrumen tersebut cukup mahal, yakni puluhan juta rupiah karena biasanya alat tersebut didatangkan dari luar negeri. Dan belum ada perusahaan dalam negeri yang membuat instrumentasi laboratorium sekolah.

Oleh karena itu penelitian ini akan dilakukan untuk merancang instrumentasi pengukur waktu dan kecepatan sebagai media pembelajaran materi gerak lurus beraturan dengan biaya yang murah menggunakan Dt-Sense Infrared Proximity

Detector dan Mikrokontroller Atmega 8 .

Oleh karena itu peneliti termotivasi untuk melakukan penelitian dengan judul "Perancang Instrumentasi Pengukur Waktu dan Kecepatan Mengunakan DT-Sense Infrared Proximity Detector untuk Pembelajaran Gerak Lurus Beraturan”.

Adapun manfaat yang ingin dicapai dari penelitian ini yaitu, dapat memberikan kontribusi penting umumnya untuk sivitas akademik sekolah dan universitas baik guru, dosen, siswa dan mahasiswa dalam mempelajari materi fisika yaitu, gerak lurus beraturan dengan menggunakan instrumentasi yang akan dirancang. Serta memberikan inovasi kepada guru, dosen dan kawan mahasiswa untuk mengembangkan instrumentasi-instrumentasi lain, yang dapat digunakan untuk media pembelajaran demi menunjang proses belajar-mengajar siswa.

Oleh karena itu, rumusan masalah yang dapat dikemukakan dalam penelitian ini adalah bagaimana merancang instrumentasi pengukur waktu dan kecepatan untuk pembelajaran materi gerak lurus lurus beraturan.

Suatu benda dapat dikatakan bergerak jika benda itu mengalami perubahan kedudukan terhadap titik tertentu sebagai acuan. Gerak dapat dikatakan sebagai perubahan kedudukan suatu benda dalam selang waktu tertentu ${ }^{[1]}$.

Dalam konsep gerak ada beberapa hal yang terkait antara lain kedudukan, waktu, kecepatan dan percepatan benda tersebut. Jika suatu benda bergerak, maka benda tersebut dapat dikatakan memiliki kecepatan, yaitu seberapa cepat kedudukan benda tersebut berubah. Definisi kecepatan adalah perubahan kedudukan / perpindahan yang ditempuh tiap satuan waktu. Secara matematis dapat ditulis sebagai berikut ${ }^{[2]}$.

$$
\bar{v}\left(\frac{m}{s}\right)=\frac{d x(m)}{d t(s)}
$$

Keterangan : 
$\bar{v}$ adalah kecepatan (meter/detik)

$x$ adalah jarak perpindahan (meter)

$t$ adalah selang waktu (detik)

Gerak suatu benda menurut lintasannya dibagi menjadi gerak lurus, gerak melingkar, dan gerak parabola. Dalam penelitian ini akan dibahas lebih lanjut tentang gerak lurus.

Suatu benda yang bergerak dalam lintasan lurus disebut gerak lurus. Beberapa contoh dari gerak lurus misalnya: Kereta api yang bergerak pada lintasannya dan buah kelapa yang jatuh dari pohonnya.

Gerak lurus dibagi menjadi dua, yaitu gerak lurus beraturan dan gerak lurus berubah beraturan.

Gerak lurus beraturanterjadi apabila ada suatu benda yang bergerak dengan kecepatan tetap (konstan). Syarat benda dikatakan bergerak lurus beraturan apabila gerak benda tersebut menempuh lintasan lurus dan kecepatan benda tidak berubah. Pada gerak lurus beraturan, tidak ada percepatan benda $(\alpha=0)^{[3]}$.

Persamaan GLB secara matematis dapat dirumuskan sebagai berikut.

$$
\bar{v}=\frac{d x}{d t} \text { atau } d x=v \cdot d t
$$

Keterangan:

$\bar{v}$ adalah kecepatan (meter/detik)

$x$ adalah jarak perpindahan (meter)

t adalah selang waktu (detik)

Secara grafik hubungan antara jarak dan kecepatan dapat digambarkan sebagai berikut:

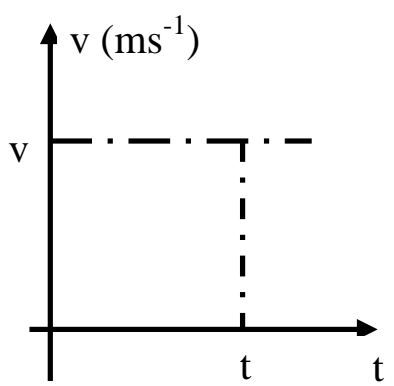

Gambar 1. Grafik Hubungan antara Jarak Terhadap Waktu pada GLB
Gerak lurus berubah beraturan terjadi apabila ada suatu benda yang bergerak pada lintasan lurus dengan kecepatan yang berubah secara teratur setiap detiknya. Perubahan kecepatan setiap detiknya ini disebut percepatan.

Dengan demikian, pada GLBB benda mengalami percepatan secara teratur atau tetap. Hubungan antara besar kecepatan $(v)$ dengan waktu $(t)$ pada gerak lurus berubah beraturan (GLBB) ditunjukkan pada grafik di bawah ini.

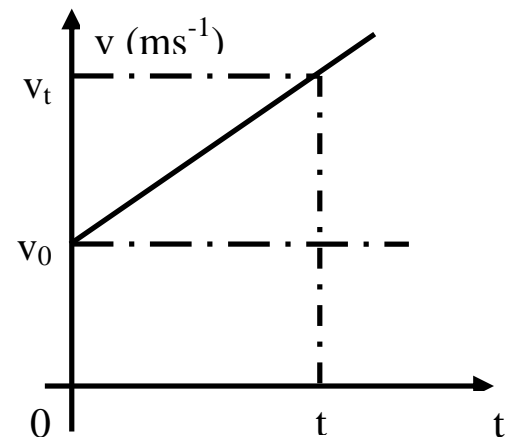

Gambar 2. Grafik Hubungan antara Jarak Terhadap Waktu pada GLBB

Mikrokontroler Atmega 8 merupakan salah satu produk dari Atmel Corp yang memiliki 8Kbytes Flash Programmable and Erasable Read-Only Memory (PEROM). Mikrokontroler ini memiliki kumpulan instruksi yang sesuai dengan standar keluarga MCS-51 produk INTEL. Atmega 8 mempunyai fitur standar sebagai berikut: tegangan kerja 2,7-5.5 Volt, kecepatan $16 \mathrm{MHz}$, 8Kbytes Flash, 512Bytes EEPROM ,1K bytes RAM, 23 jalur I/O, 2 timer/ counter 8-bit, 1 timer/ counter 16-bit, 3 jalur PWM, 8 jalur ADC, serial interface ada, Programmable Watchdog Timer with Separate On-chip Oscillator, On-chip Analog Comparator ${ }^{[4]}$.

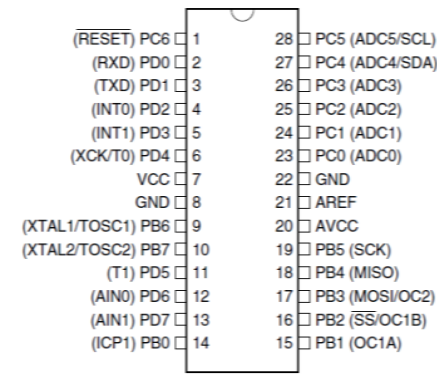

Gambar 3. konfigurasi pin Atmega 8 sumber: datasheet Atmega 8 
Mikrokontroler Atmega 8 yang merupakan dilengkapi dengan 3 perangkat Timer / Counter, yang masing-masing dinamakan sebagai timer 0 , timer 1 dan timer 2. Pada dasarnya sarana input yang satu ini merupakan seperangkat pencacah biner (binary counter). Jika pencacah tersebut bekerja dengan frekuensi tetap yang sudah diketahui besarnya, maka dikatakan sebagai timer, karena kedudukan pencacah tersebut setara dengan waktu yang bisa ditentukan dengan pasti. Namun jika pencacah tersebut bekerja dengan frekuensi yang tidak tetap, maka dikatakan sebagai counter, karena kedudukan pencacah tersebut hanyalah menyatakan banyaknya pulsa yang sudah diterima pencacah ${ }^{[5]}$.

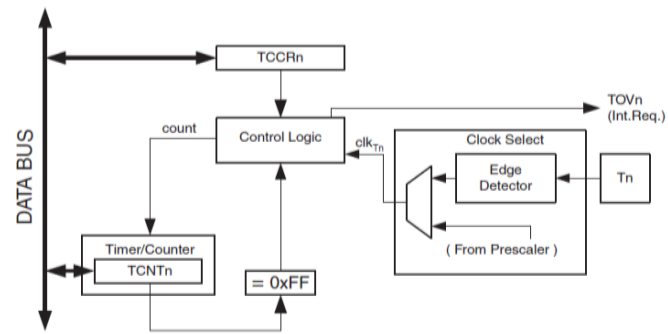

Gambar 4. Diagram Blok Timer 0 sumber: datasheet Atmega 8

Dt-Sense IR Proximity Detector merupakan sebuah modul sensor cerdas yang dapat digunakan untuk mendeteksi ada tidaknya suatu obyek. Keluaran Dt-Sense IR Proximity Detector berupa data digital yang menyatakan ada atau tidaknya obyek hingga jarak tertentu di depan sensor. Jarak deteksi sensor dapat ditentukan oleh pengguna. Modul sensor ini dilengkapi dengan antarmuka UART TTL dan I2C. Contoh aplikasi Dt-Sense IR Proximity Detector antara lain untuk sistem robot cerdas, proximity switch, atau aplikasi-aplikasi lain yang menggunakan informasi deteksi jarak [6].

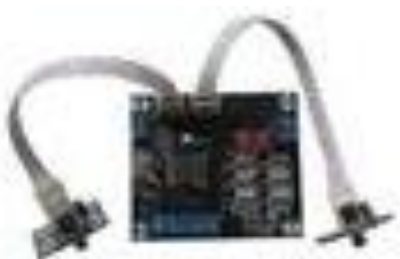

Gambar 5. Modul Dt-Sense IR Proximity Detector sumber: http://innovativeelectronics.com

\section{METODE PENELITIAN}

Metote penelitian yang digunakan dalam penelitian ini adalah penelitian dimulai dengan studi literatur yang berkaitan dengan penelitian, mensimulasikan metode yang telah ditentukan, perancangan alat ukur, dan uji coba alat yang telah dibuat.

Perancangan alat pengukur waktu dan kecepatan ini direalisasikan dengan komponen yang mudah didapat. Komponen dasar untuk rangkaian alat pengukur waktu dan kecepatan terdiri atas :

- Perangkat Keras/Hardware

- Perangkat lunak/Software

Prinsip kerja dari alat pengukur waktu dan kecepatan ini adalah Menggunakan $D t$ Sense IR Proximity Detector yang berfungsi sebagai saklar untuk memulai dan menghentikan timer yang di hitung oleh mikrokontroler Atmega 8. Perhitungan timer ini berfungsi untuk mengetahui berapa waktu yang diperlukan sebuah benda yang bergerak melintasi jalan sepanjang DT-Sense IR Proximity Detector.

Perancangan perangkat keras (hardware) dari alat pengukur waktu dan kecepatan terdiri atas : rangkaian mikrokontroler, rangkaian sensornya, dan rangkaian pengatur Tegangan mobil. Sebelum pembuatan hardware terlebih dahulu disimulasikan menggunakan software Isis 7 Profesional untuk mengetahui rangkaian yang digunakan berfungsi dengan benar. Berikut ini adalah simulasi rangkaian yang digunakan:

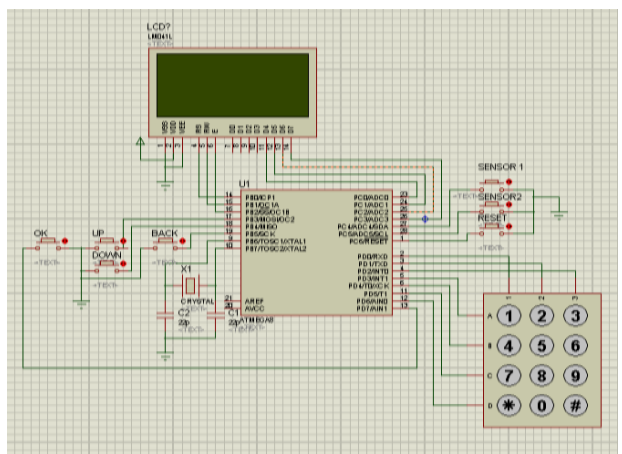

Gambar 6. Rangkaian Mikrokontroler dan Sensor 


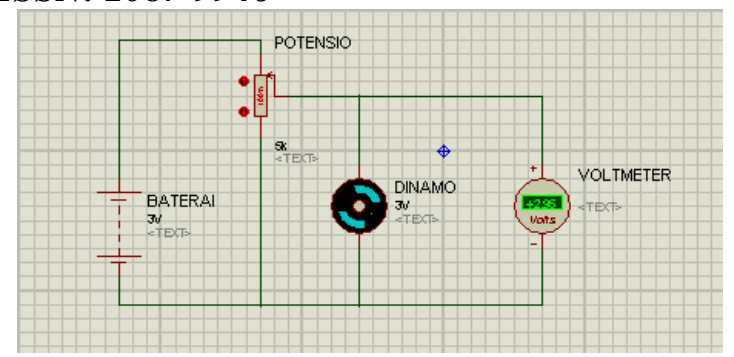

Gambar 7.Rangkaian Pengatur Tegangan Mobil

Perancangan perangkat lunak atau software diperlukan untuk menjalankan intruksi-intruksi input output apa yang harus dilakukan sebuah perangkat keras, yaitu mikrokontroler. Sehingga dibutuhkan software CV AVR yang berbasis bahasa C untuk menulis intruksi apa saja yang ingin dilakukan $^{[7]}$.

Berikut adalah diagram alir program alat pengukur waktu dan kecepatan.

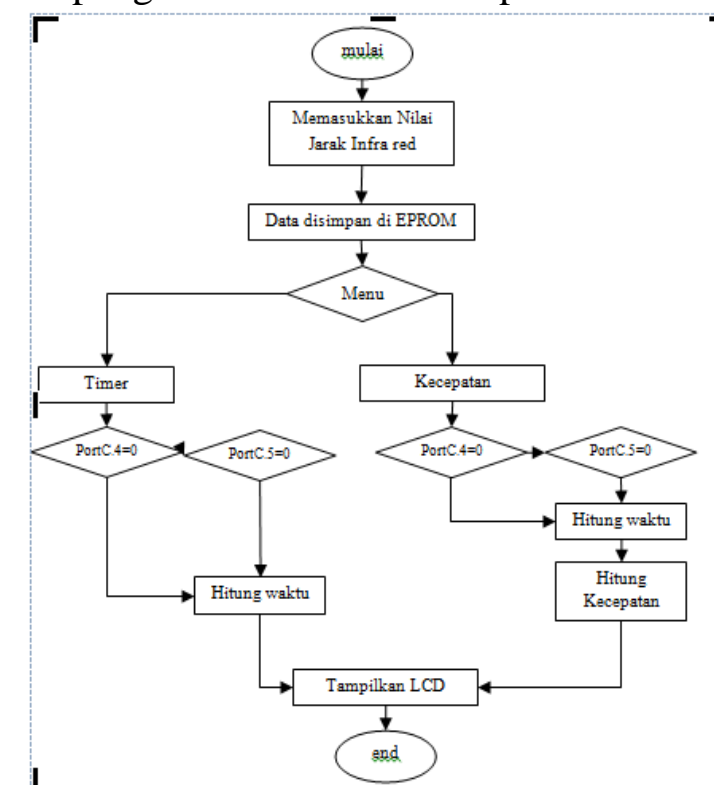

Gambar 8. Diagram Alir Program Alat Pengukur Waktu dan Kecepatan

Pengujian smart timer sebagai alat pengukur waktu dan kecepatan dilakukan dengan metode percobaan yang nanti hasilnya akan dibandingkan dengan alat mengukur waktu yaitu stopwatch. Metode pengujian yang digunakan seperti gambar dibawah ini:

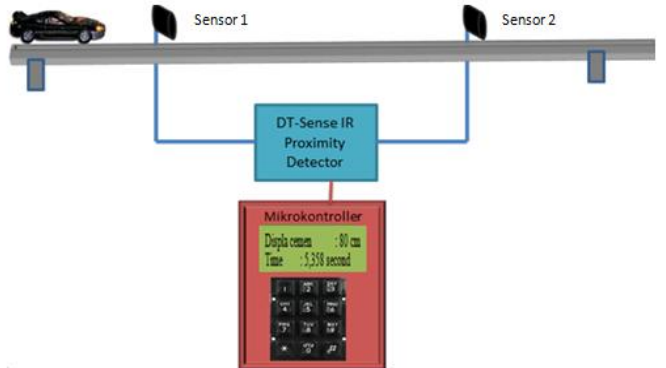

Gambar 9. Rancangan Instrumentasi Pengukur Waktu dan Kecepatan

Nilai tegangan yang digunakan pada mobil adalah $1 ; 1,5$;dan 2 Volt dan jarak yang digunakan adalah 80,100, $120 \mathrm{~cm}$.

\section{HASIL DAN PEMBAHASAN}

Hasil penelitian dari tahap perancangan yang telah dilaksanakan diperoleh sebuah alat ukur waktu dan kecepatan, lintasan lurus, dan mobil mainan dengan pengatur tegangan. Setelah diperoleh hasil dari perancangan alat ukur waktu dan kecepatan, dilakukan tahap selanjutnya yaitu tahap pengujian.

Berikut ini adalah tabel data hasil pengujian alat ukur dan stopwatch untuk menentukan nilai waktu yang terukur ketika mobil mainan melintasi sensor:

Tabel 1. Data Hasil Pengujian Alat dan Stopwatch untuk Menentukan Waktu

\begin{tabular}{|r|c|c|c|c|c|c|c|}
\hline \multirow{2}{*}{ No. } & \multirow{2}{*}{$\begin{array}{c}\text { Tegangan } \\
\text { (Volt) }\end{array}$} & \multicolumn{2}{|c|}{ Jarak $80 \mathrm{Cm}$} & \multicolumn{2}{|c|}{ Jarak $100 \mathrm{Cm}$} & \multicolumn{2}{|c|}{ Jarak $120 \mathrm{Cm}$} \\
\cline { 3 - 8 } & & Stopwatu Terukur(s) & \multicolumn{2}{|c|}{ WaktuTerukur(s) } & \multicolumn{2}{|c|}{ WaktuTerukur(s) } \\
\hline 1 & 1.00 & 5.58 & 6.01 & 7.35 & 7.75 & 9.38 & 9.70 \\
\hline 2 & 1.00 & 5.72 & 5.90 & 7.78 & 7.94 & 9.08 & 9.29 \\
\hline 3 & 1.00 & 5.32 & 5.45 & 7.46 & 7.76 & 9.08 & 9.30 \\
\hline 4 & 1.00 & 5.50 & 5.77 & 7.78 & 7.96 & 9.00 & 9.30 \\
\hline 5 & 1.00 & 5.71 & 6.20 & 7.85 & 8.18 & 8.91 & 9.03 \\
\hline 6 & 1.50 & 3.74 & 4.00 & 4.44 & 4.68 & 5.71 & 5.79 \\
\hline 7 & 1.50 & 3.07 & 3.36 & 4.55 & 4.69 & 5.39 & 5.57 \\
\hline 8 & 1.50 & 3.27 & 3.57 & 4.71 & 4.79 & 5.67 & 5.77 \\
\hline 9 & 1.50 & 3.91 & 4.10 & 4.64 & 4.69 & 5.35 & 5.38 \\
\hline 10 & 1.50 & 3.65 & 3.80 & 4.89 & 5.12 & 5.82 & 6.10 \\
\hline 11 & 2.00 & 2.57 & 3.21 & 3.96 & 4.24 & 4.79 & 4.92 \\
\hline 12 & 2.00 & 2.81 & 3.02 & 3.96 & 4.12 & 4.66 & 4.93 \\
\hline 13 & 2.00 & 2.89 & 3.15 & 3.78 & 3.98 & 4.74 & 5.12 \\
\hline 14 & 2.00 & 3.00 & 3.15 & 3.85 & 4.07 & 4.04 & 4.19 \\
\hline 15 & 2.00 & 3.08 & 3.07 & 3.94 & 4.20 & 5.00 & 5.12 \\
\hline
\end{tabular}

Hasil pengujian pada tabel 1 menunjukkan bahwa alat ukur waktu dan kecepatan yang telah dirancang menggunakan sensor DT-Sence Infrared Proximity Detector berhasil mendeteksi 
ISSN: 2087-9946

adanya halangan dari mobil yang melintasi lintasan lurus. Berikut ini waktu rata-rata dan perhitungan kecepatan secara teori dari data hasil pengujian alat dan stopwatch untuk menentukan waktu dari tabel 2:

Tabel 2 .Data Rata-rata Hasil Pengujian Alat untuk Menentukan Waktu

\begin{tabular}{|c|c|c|c|}
\hline $\begin{array}{c}\text { Tegangan } \\
\text { (Volt) }\end{array}$ & Jarak (Cm) & $\begin{array}{c}\text { Waktu Terukur } \\
\text { r ata-rata (s) }\end{array}$ & $\begin{array}{c}\text { Kecepatan Teori } \\
\text { rata-rata(Cm/s) }\end{array}$ \\
\hline \multirow{3}{*}{1.00} & 80 & 5.87 & 13.64 \\
\cline { 2 - 4 } & 100 & 7.92 & 12.63 \\
\cline { 2 - 4 } & 120 & 9.32 & 12.87 \\
\hline \multirow{3}{*}{1.50} & 80 & 3.77 & 21.24 \\
\cline { 2 - 4 } & 100 & 4.79 & 20.86 \\
\cline { 2 - 4 } & 120 & 5.72 & 20.97 \\
\hline \multirow{3}{*}{2.00} & 80 & 3.12 & 25.64 \\
\cline { 2 - 4 } & 100 & 4.12 & 24.26 \\
\cline { 2 - 4 } & 120 & 4.86 & 24.71 \\
\hline
\end{tabular}

Dari data pada tabel 2 diperoleh grafik hubungan antara jarak benda dan waktu terukur seperti dalam grafik dibawah ini:

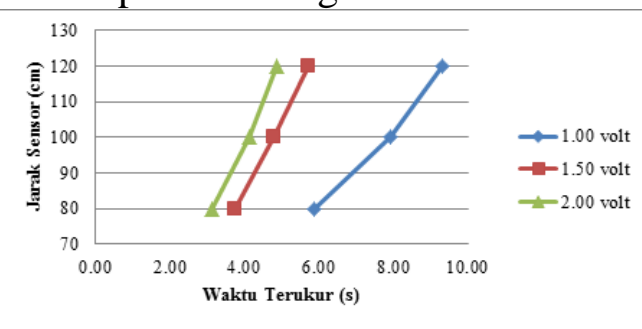

Gambar 10. Grafik Hubungan Antara Jarak Sensor terhadap Waktu Terukur pada Alat

Dari gambar 10 tampak bahwa semakin besar jarak sensor DT-Sence Infrared Proximity Detector out1 dan out2, maka semakin besar pula nilai waktu yang terukur pada alat, dan sebaliknya. Besarnya nilai waktu yang terukur sesuai dengan persamaan gerak lurus beraturan (GLB) 2.2 dimana $\mathrm{t}$ (waktu) berbanding lurus dengan jarak (x). Berikut ini adalah grafik hubungan antara waktu dan kecepatan pada alat dari tabel 2:

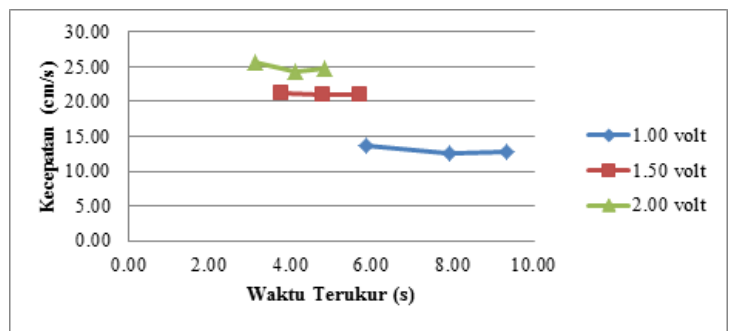

Grafik 11. Grafik Hubungan Waktu dan Kecepatan pada Alat
Dari gambar 11 tampak bahwa kecepatan yang dihasilkan dari mobil tetap untuk waktu apapun. Hal ini membuktikan bahwa mobil bergerak lurus beraturan dimana kecepatan (v) konstan atau tetap.

Berikut ini adalah tabel data hasil pengujian alat ukur dan stopwatch untuk menentukan nilai kecepatan yang terukur:

Tabel 3. Data Hasil Pengujian Alat dan Stopwatch untuk Menentukan Kecepatan

\begin{tabular}{|c|c|c|c|c|c|c|c|}
\hline \multirow[b]{2}{*}{ No. } & \multirow[b]{2}{*}{$\begin{array}{l}\text { Togangan } \\
\text { (Vnlt) }\end{array}$} & \multicolumn{2}{|c|}{ Jarak $00 \mathrm{Cm}$} & \multicolumn{2}{|c|}{ Jarak $100 \mathrm{~cm}$} & \multicolumn{2}{|c|}{ Jarak $120 \mathrm{Cm}$} \\
\hline & & $\begin{array}{c}\text { Kecpatan } \\
(\mathrm{r} / \mathrm{m} / \mathrm{s})\end{array}$ & $\begin{array}{l}\text { Waktu } \\
\text { Terultur } \\
\text { (s) }\end{array}$ & $\begin{array}{c}\text { Keccpatan } \\
(\mathrm{r} / \mathrm{m} / \mathrm{s})\end{array}$ & $\begin{array}{l}\text { Waktu } \\
\text { Teruldur } \\
(\xi)\end{array}$ & $\begin{array}{c}\text { Koceppatan } \\
(\mathrm{r} / \mathrm{m} / \mathrm{s})\end{array}$ & $\begin{array}{c}\text { Waktu } \\
\text { Terultur } \\
(\Leftrightarrow)\end{array}$ \\
\hline 1 & $1.0 n$ & 11.13 & 6.24 & 12.50 & 8.22 & 13.33 & 9.18 \\
\hline 2 & 100 & 11,40 & 6.36 & 12.50 & 0.20 & 13.35 & 2.12 \\
\hline 3 & 100 & 11,43 & 618 & 12.50 & 8.02 & 13.33 & 9.30 \\
\hline 4 & 100 & 11,43 & 634 & 12.60 & 8.20 & 13.53 & Y.:33 \\
\hline$b$ & 100 & 11.43 & 639 & 12.50 & 8.25 & 13.33 & 9,47 \\
\hline 6 & 150 & 20.00 & 3.62 & 25.00 & 4.86 & 24.00 & 5.55 \\
\hline 7 & 1.50 & 20.00 & 3.82 & 25.00 & 4.84 & 24.00 & 5.34 \\
\hline 8 & 150 & 20.00 & 3.63 & 25.00 & 4.74 & 24.00 & 5.76 \\
\hline 9 & 150 & 20.00 & 3.55 & 25.00 & 4.68 & 24.00 & 5.58 \\
\hline 10 & 1.50 & $2 n . n n$ & 378 & $25 . n n$ & 4.42 & $24.0 n$ & 5.18 \\
\hline 11 & 2.00 & 26.67 & 3.17 & 33.33 & 3.98 & 30.00 & 4.79 \\
\hline 12 & 200 & 26,07 & 3.21 & 33.35 & 3.00 & 50.00 & 4,00 \\
\hline 13 & 200 & 26.67 & 3.24 & 33.33 & 4.02 & 30.00 & 4,60 \\
\hline 14 & 200 & 26.67 & 3.14 & 33.33 & 3.70 & 30.00 & 4.84 \\
\hline 15 & 200 & 26.67 & 3.11 & 33.33 & 3.88 & 30.00 & 4.58 \\
\hline
\end{tabular}

Dari data pada tabel 3 tampak semakin besar jarak sensor DT-Sence Infrared Proximity Detector out1 dan out2, maka semakin besar pula nilai waktu yang terukur. Besarnya nilai waktu yang terukur sesuai dengan persamaan gerak lurus beraturan (GLB) 2.2 dimana $t$ (waktu) berbanding lurus dengan jarak (x).

Dari tabel 3 diperoleh perbedaan nilai kecepatan alat dan kecepatan secara perhitungan (kecepatan teori) perbedaan ini disebabkan karena keterbatasan mikrokontroler atmega 8 untuk menghitung kecepatan dari waktu yang terukur secara cepat dengan nilai waktu terukur yang berbeda-beda setiap milisekonnya. Hal ini menyebabkan perancangan alat ukur kecepatan masih belum sempurna, karena hasil pengukuran dan teori masih memiliki perbedaan. Tetapi dari penelitian ini dapat dibuktikan bahwa sensor DT-Sence Infrared Proximity Detector dapat digunakan untuk merancang alat ukur waktu dan kecepatan sebagai pembelajaran gerak lurus beraturan. 


\section{SIMPULAN DAN SARAN}

Berdasarkan hasil analisis didapatkan simpulan bahwa: DT Sense Infrared Proximity Detector dapat digunakan dalam perancangan instrumentasi pengukur waktu dan kecepatan yang dapat digunakan untuk pembelajaran materi fisika gerak lurus beraturan. Instrumentasi yang dihasilkan dapat digunakan sebagai media penunjang yang akan membantu siswa ataupun mahasiswa dalam memahami materi fisika khususnya materi gerak lurus beraturan.

Dengan memperhatikan hasil penelitian di atas, maka saran yang dapat diberikan berkenaan pengambilan data menggunakan alat yang telah dirancang dapat dilaksanakan dalam semua bidang , misalnya bidang miring atau menggunakan variasi mengukur waktu dan kecepatan dengan benda yang bergerak lurus berubah beraturan.

Selain itu yang dapat kami sampaikan untuk teman-teman mahasiswa yang lain ataupun civitas akademik, dapat melaksanakan penelitian perancangan alat waktu dan kecepatan menggunakan sensor yang lain ataupun melaksanakan penelitian lain dengan memanfaatkan fungsi lain dari sensor DT Sense Infrared Proximity Detector.

\section{UCAPAN TERIMA KASIH}

Tim Peneliti menyampaikan terima kasih kepada LPPM UNESA karena telah mendanai penelitian ini, serta peneliti menyampaikan terima kasih kepada semua pihak yang telah membantu dalam menyelesaikan penelitian ini.

\section{DAFTAR PUSTAKA}

[1] Halliday D., Resnick R. (1997). Fisika Jilid 1. Jakarta: Erlangga.

[2] Prasetio, L. (1992). Mengerti Fisika.. Yogyakarta: Andi Offset.

[3] Winarsih, A. (2008). IPA Terpadu Untuk SMP/Mts. Jakarta: Gramedia Widiasarana Indonesia.

[4] Corporation, A. (2011). Datasheet ATMEGA 8. San Jose, Canada, USA: Atmel Corporation.

[5] timer dan counter. (2011, juni 27). Retrieved juli 1, 2013, from elektro kontrol: http://elektro_kontrol.blogspot.com

[6] Quick Start Dt-Sense IR Proximity Detector. Retrieved juli 1, 2013, from:

http://innovativeelectronics.com

[7] Sudjadi. (2005). Teori dan Aplikasi Mikrokontroler. Yogyakarta: Graha Ilmu. 